\title{
Perancangan Aplikasi Berbasis Komputer untuk Proses Manajemen Mutu pada Pembangunan Kapal Baru
}

\author{
Renny Rahmadi Putra dan Triwilaswandio Wuruk Pribadi \\ Jurusan Teknik Perkapalan, Fakultas Teknologi Kelautan, Institut Teknologi Sepuluh Nopember (ITS) \\ Jl. Arief Rahman Hakim, Surabaya 60111 Indonesia \\ e-mail: triwilas.its@gmail.com
}

\begin{abstract}
Abstrak- Manajemen mutu di galangan kapal saat ini belum dilaksanakan dengan sistematis. Hasil proses pemeriksaan pembangunan kapal baru, masih disimpan di dalam lemari dan folder-folder komputer secara terpisah. Manajemen pemeriksaan belum didukung dengan sistem yang mempermudah pihak Galangan, Owner Surveyor, Class dan State Regulator dalam pengawasan, pencarian, review, evaluasi dan pelaksanaan pemeriksaan. Tugas akhir ini bertujuan untuk merancang aplikasi berbasis komputer dalam membantu pelaksanaan manajemen mutu pada pembangunan kapal baru yang lebih baik. Pertama, dilakukan observasi sistem manajemen mutu di galangan kapal, diambil sebagai sampel adalah Galangan PT. PAL Indonesia. Kedua, ditentukan parameter-parameter yang diperlukan dalam aplikasi manajemen mutu. Ketiga, dilakukan perancangan aplikasi manajemen mutu berdasarkan parameter-parameter aplikasi. Parameter-parameter di dalam aplikasi diidentifikasi selama tahapan pembangunan kapal, proses, komponen kapal dan dokumen kapal, serta item pemeriksaan dan standar pemeriksaan. Software yang digunakan untuk perancangan aplikasi adalah kombinasi bahasa pemograman PHP, text editor Sublime Text 2 dan database MySQL. Aplikasi berbasis komputer yang dirancang dapat membantu pelaksanaan manajemen mutu dalam pengawasan, pencarian, review, evaluasi dan pelaksanaan pemeriksaan. Setelah aplikasi dibuat, dilakukan uji perbandingan sistem dan uji verifikasi, didapatkan hasil bahwa aplikasi lebih baik dibandingkan dengan sistem eksisting yang secara perseorangan dijalankan di galangan kapal.
\end{abstract} Kapal.

Kata Kunci : Aplikasi, Manajemen Mutu, Pembangunan

\section{PENDAHULUAN}

$\mathrm{P}$ EMERIKSAAN proses pembangunan kapal sangat penting dilakukan, untuk menghindari tindakan kesalahan-kesalahan pada proses pembangunan yang dapat menurunkan kualitas/mutu kapal yang dibangun oleh sebuah galangan. Setiap pemeriksaan yang dilakukan oleh Galangan, Owner Surveyor, Class dan State Regulator akan menghasilkan dokumen hasil pemeriksaan. Kebanyakan galangan kapal di Indonesia, proses pemeriksaan yang dilakukan oleh Quality Control dan Quality Assurance sebuah galangan biasanya menggunakan check sheet, sehingga dokumen hasil pemeriksaan ini berupa lembaran check sheet [1].

Manajemen pemeriksaan masih dilakukan dengan cara manual seperti hasil pemeriksaan yang berbentuk lembaran kertas disimpan di dalam lemari dan scan disimpan di dalam folder-folder komputer secara terpisah. Hasil pemeriksaan tersebut tidak mendukung manajemen pemeriksaan dalam pengawasan, pencarian, review, evaluasi dan pelaksanaan pemeriksaan. Hasil pemeriksaan yang jumlahnya sangat banyak, sangat rentan dengan kesalahan, dan kehilangan data. Dibutuhkan media tambahan yang dapat membantu manajemen pemeriksaan seperti halnya aplikasi komputer yang mampu mengolah hasil pemeriksaan ke dalam komputer yang terpusat dalam satu program dan mengintegrasikan hasil pemeriksaan sehingga mampu menampilkan informasi-informasi tambahan kepada pengguna. Jika manajemen pemeriksaan berjalan baik maka manajemen mutu di galangan kapal akan berjalan baik juga, dikarenakan manajemen pemeriksaan merupakan bagian dari pelaksanaan manajemen mutu galangan kapal.

Perkembangan sistem komputerisasi akan membantu dalam penerapan sebuah sistem aplikasi komputer dalam pelaksanaan manajemen mutu pada pembangunan kapal baru. Aplikasi komputer untuk proses manajemen mutu pembangunan kapal baru ini mampu memberikan beberapa pelayanan, seperti memasukkan, menyimpan, menampilkan, mencetak, mencari, mengawasi dan mengevaluasi pemeriksaan, sehingga aplikasi ini akan lebih tepat guna dalam hal mendukung peningkatan mutu/kualitas kapal yang dibangun.

\section{TINJAUAN PUSTAKA}

\section{A. Manajemen Mutu}

Manajemen mutu dijalankan dengan memutarkan siklus PDCA (Plan - Do - Check - Action), yaitu melakukan perencanaan, pengerjaan, evaluasi dan aksi perbaikan terhadap masalah yang berkaitan dengan kualitas. Sehingga mutu yang ditetapkan oleh perusahaan merupakan sebuah hasil dari proses manajemen atau sering dikenal dengan sebutan manajemen mutu [2].

\section{B. Proses Pembangunan Kapal}

Pada Gambar 1, menunjukkan proses pembangunan kapal dimulai dari pendefinisian keinginan pemilik kapal (Owner Requirement), perancangan (desain) kapal, kontrak, dan proses pembangunan kapal. Proses pembangunan kapal merupakan kumpulan dari proses perencanaan, penjadwalan dan produksi. Proses produksi kapal memegang peranan utama dalam pembangunan kapal. Kualitas kapal yang dibangun sangat dipengaruhi oleh bagaimana proses produksi dijalankan, diawasi dan diperiksa. Proses produksi 
kapal merupakan sebuah multi proses yang dijalankan secara seri. Proses produksi kapal meliputi tahapan identifikasi komponen, fabrikasi, assembly, erection, outifitting, launching, commissioning, sea trial dan delivery [3].

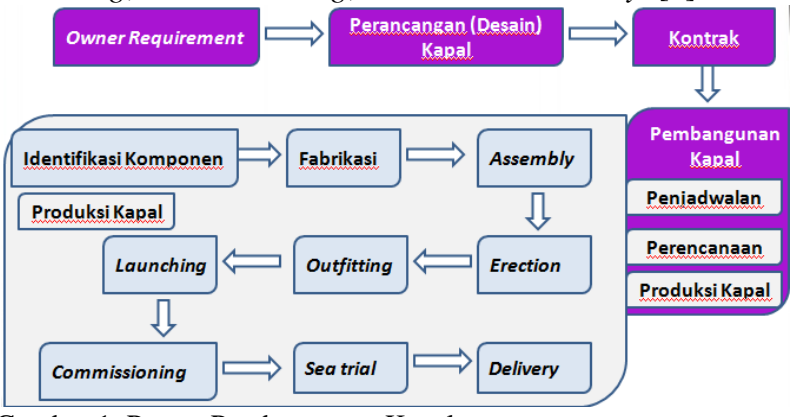

Gambar 1. Proses Pembangunan Kapal

\section{Kualitas dan Standarisasi Pembangunan Kapal Baru}

Pengendalian Kualitas dilakukan dengan rangkaian pemeriksaan atau pengawasan termasuk pengujian untuk mendapatkan suatu jaminan bahwa kapal meliputi segenap komponen-komponen permesinan, sistem kelistrikan, perlengkapan beserta seluruh peralatan yang meliputi aspek kualitas material, sistem fabrikasi, sistem manufaktur dan instalasi komponen telah sesuai dengan spesifikasi teknik, peraturan klasifikasi kapal, peraturan kesyahbandaran, dan standar yang telah disepakati bersama antara owner dan shipyard. Pemeriksaan dan pengujian yang dilakukan mengacu pada kontrak yang disepakati serta peraturan Klasifikasi, Standar Kualitas Galangan, IACS Shipbuilding Standards, SOLAS dan Peraturan IMO.

\section{Aplikasi Komputer}

Aplikasi berbasis komputer merupakan sebuah sistem pengolah data menjadi sebuah informasi yang berkualitas dan dipergunakan untuk suatu alat bantu pengambil keputusan [4]. Aplikasi ini mengintegrasikan antara manusia dengan mesin yang memanfaatkan perangkat keras dan perangkat lunak komputer, prosedur dan basis data yang bertujuan untuk menyediakan informasi yang mendukung operasi, manajemen dan fungsi pengambilan keputusan di dalam perusahaan. Aplikasi dibangun dengan bahasa pemograman untuk memasukkan intruksi yang dijalankan aplikasi, contoh bahasa pemograman PHP [5]. Pemograman aplikasi dibantu dengan menggunakan text editor untuk memformulasikan bahasa pemograman dari aplikasi contoh text editor Sublime Text 2. Selain itu aplikasi komputer juga didukung oleh software lain yang mana aplikasi menjalankan data didalam software tersebut seperti halnya software database MySQL untuk sistem informasi manajemen [5].

\section{E. Struktur Data}

Hal-hal yang perlu diperhatikan di dalam perancangan aplikasi adalah tipe struktur data yang didefinisikan di dalam sistem atau metode yang diberikan untuk menjalankan aplikasi. Struktur data dapat disajikan dalam bentuk Database, Data Flow Diagram, Entity Relationship Diagram dan Use Case Diagram. Database adalah kumpulan semua data yang disimpan dalam satu file atau beberapa file. Data Flow Diagram (DFD) merupakan diagram yang digunakan untuk menggambarkan proses- proses yang terjadi pada sistem yang akan dikembangkan. Use Case Diagram (UCD) merupakan metode berbasis teks untuk menggambarkan dan mendokumentasikan proses yang kompleks. Entity Relationship Diagram (ERD) adalah gambar atau diagram yang menunjukkan informasi dibuat, disimpan dan digunakan dalam aplikasi [6].

\section{URAIAN PENELITIAN}

\section{A. Tahap Pengumpulan Data}

Pengumpulan Data dilakukan melalui studi literatur dan survei lapangan. Data yang dikumpulkan adalah data pemeriksaan selama proses pembangunan kapal baru mulai dari tahapan identifikasi komponen sampai tahapan delivery. Survei lapangan dilakukan di Galangan Kapal, yang diambil sebagai sampel adalah Galangan PT. PAL Indonesia (Persero).

\section{B. Tahap Pengolahan Data}

Pengolahan data dilakukan dengan mengacu pada observasi studi kondisi awal sistem dan pengumpulan data. Pada tahapan ini dilakukan pengelompokan data berdasarkan tahapan pembangunan kapal, proses, komponen kapal, standar dan item pemeriksaan. Dari pengolahan data, dihasilkan parameter-parameter di dalam aplikasi yang diidentifikasi selama tahapan pembangunan kapal, proses, komponen dan dokumen kapal, serta item dan standar pemeriksaan.

\section{Tahap Perancangan Aplikasi}

Perancangan aplikasi dilakukan melalui beberapa tahapan yaitu pemodelan aplikasi, perancangan interface, perancangan database, dan pengkodingan aplikasi. Pemodelan aplikasi digambarkan melalui use case diagram, data flow diagram dan entity relationship diagram. Perancangan interface digambarkan dengan desain mock up aplikasi. Perancangan database aplikasi menggunakan software MySQL. Pengkodingan aplikasi merupakan tahap paling penting dalam perancangan aplikasi, pengkodingan dilakukan menggunakan software text editor Sublime Text 2 dan bahasa pemograman PHP.

\section{Tahap Validasi Aplikasi}

Pengujian validasi dilakukan secara offline maupun online, untuk memastikan program aplikasi manajemen mutu tersebut dapat digunakan dan berjalan dengan baik. Pengujian Offline dilakukan dengan menggunakan localhost dan pengujian online menggunakan koneksi internet yang terhubung dengan server. Aplikasi yang telah dibuat diuji perbandingan sistem dan diuji verifikasi melalui penggunaan aplikasi secara langsung dan kuesioner penilaian responden terhadap aplikasi.

\section{PERANCANGAN APLIKASI}

\section{A. Pemodelan Aplikasi}

Sebelum melakukan pemodelan aplikasi, parameterparameter aplikasi harus ditentukan terlebih dahulu. Parameter-parameter dalam aplikasi diidentfikasi selama tahapan pembangunan kapal, proses, komponen dan 
dokumen kapal, serta item dan standar pemeriksaan. Pemodelan aplikasi bertujuan untuk mempermudah mengkomunikasikan maksud dan tujuan aplikasi kepada programmer ataupun User. Pemodelan aplikasi dibuat dalam bentuk diagram alir (flowchart) menggunakan data flow diagram, use case diagram dan entity relationship diagram.

\section{B. Perancangan Aplikasi Komputer}

Perancangan aplikasi dimulai dari tahap perancangan interface. Perancangan interface aplikasi digambarkan dengan desain mock up aplikasi. Perancangan Interface sangat diperlukan untuk memudahkan dalam perencanaan konten-konten apa saja yang ditampilkan didalam aplikasi, dimana konten tersebut berisi parameter -parameter aplikasi. Aplikasi komputer yang dirancang merupakan aplikasi yang menampilkan informasi-informasi yang telah tersimpan di dalam database sistem. Database di dalam aplikasi dibangun dengan menggunakan software MySQL.

Setelah interface dan database dari aplikasi telah dirancang, maka tahapan selanjutnya yang dilakukan adalah pengkodingan sistem dengan memasukkan bahasa pemograman ke dalam text editor. Aplikasi komputer dibangun dengan menggunakan program Sublime Text 2 sebagai text editor, dan program PHP sebagai bahasa pemogramannya. Pada dasarnya program PHP merupakan program yang berbasis web, penggunaan PHP dapat menambah nilai guna aplikasi yang dapat digunakan secara online.

\section{Simulasi Aplikasi Manajemen Mutu}

Aplikasi ini melibatkan 8 User. User dibagi menjadi 2 bagian yaitu Internal Galangan (QA, QC, Desain, Pengadaan, dan Produksi) dan Eksternal Galangan (Class, Owner Surveyor dan State Regulator). Admin merupakan main User dari aplikasi manajemen mutu, Admin berkuasa penuh terhadap aplikasi. Admin didalam aplikasi dibagi dalam dua jenis yaitu QA Engineering (Admin Utama) dan QC/QA (Admin Lapangan). Pihak Admin memiliki hak untuk melakukan pengisian data, penyimpanan data, penyuntingan data, penambahan data, pengunduhan data, persetujuan pendaftar, menghapus pendaftar, menghapus data, melihat data dan pencetakan data. Sedangkan User hanya memiliki hak akses untuk melakukan pencetakan data, pengunduhan data dan melihat data.

1. Admin

Simulasi aplikasi manajemen mutu untuk Admin adalah sebagai berikut,

\section{a. Login}

Halaman login adalah halaman paling awal dari program aplikasi komputer. Dengan membuka browser dan menuliskan alamat www.qualitycheck.esy.es pada field address, maka Admin masuk pada halaman login dari aplikasi seperti pada Gambar 2.

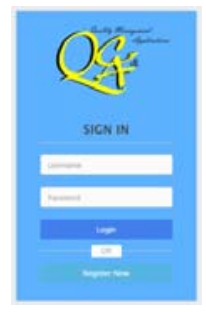

Gambar 2. Halaman Login

\section{b. Мenu}

Setelah login, maka Admin masuk ke halaman awal aplikasi. Pihak Admin melakukan pemilihan project dengan meng-klik menu Lihat Project seperti pada Gambar 3 untuk menentukan project mana yang akan diolah.

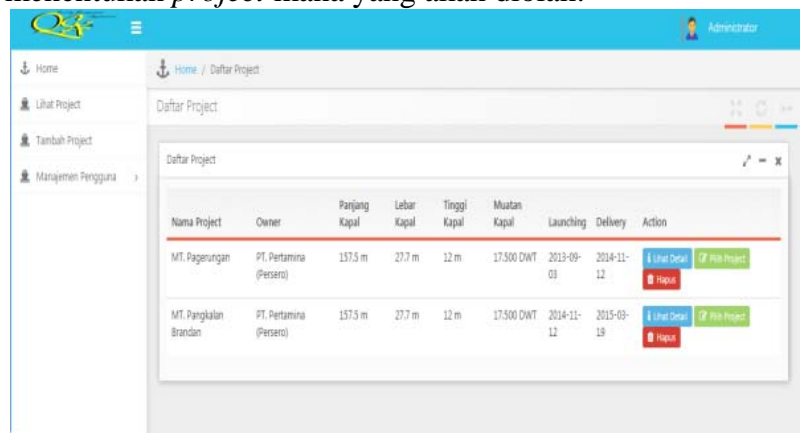

Gambar 3. Halaman Menu Lihat Project

Jika project yang dipilih tidak terdapat dalam daftar project, maka dilakukan penambahan data project. Admin meng-klik menu Tambah Project maka muncul halaman tambah project yang berisikan data identitas kapal.

Admin yang telah melakukan pemilihan project akan masuk ke dalam menu proses pembangunan kapal. Menu yang tersedia di dalam aplikasi terbagi menjadi dua yaitu menu utama dan menu tambahan. Menu utama meliputi tahapan identifikasi komponen, fabrikasi, assembly, erection, outfitting, launching, commissioning, seatrial, dan delivery. Serta menu tambahan yang tersedia dalam aplikasi meliputisearch, reject, report, evaluasi dan rekomendasi.

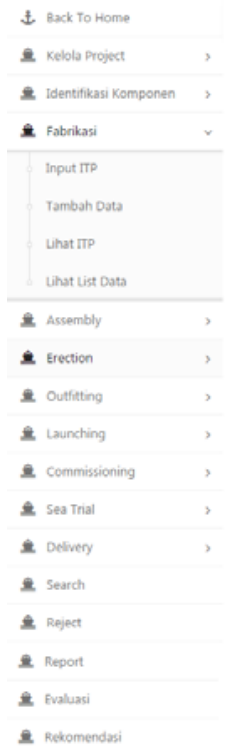

Gambar 4. Tampilan Menu dan Sub Menu (Input ITP, Tambah Data, Lihat ITP dan Lihat List Data).

Pada Gambar 4, terlihat di dalam setiap menu utama pihak Admin memiliki sub menu berupa Input ITP, Tambah Data, Lihat ITP dan Lihat List Data. Seperti pada Gambar 5 dan Gambar 6. dilakukan input ITP dan penambahan data tahapan Fabrikasi. Sedangkan pada Gambar 7 dan Gambar 8, pihak Admin melihat ITP dan data hasil pemeriksaan Assembly. 


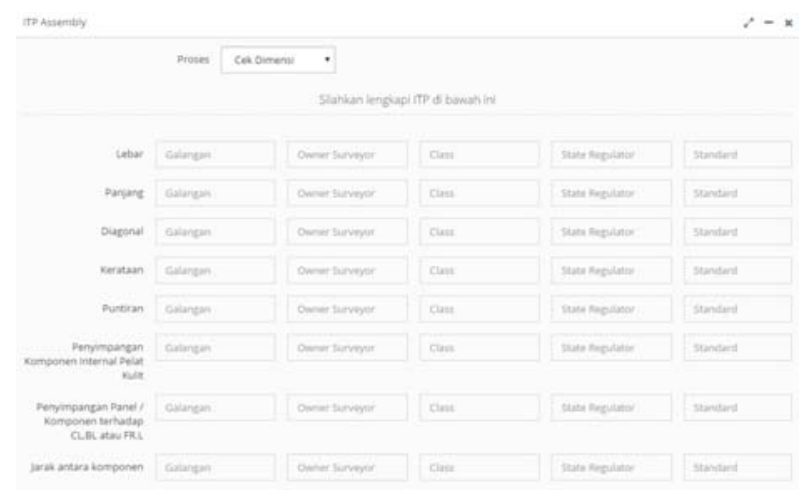

Gambar 5. Halaman Input ITP

Seperti pada Gambar 5, di Halaman Input ITP pihak Admin memasukkan item pemeriksaan apa saja yang harus diperiksa oleh pihak Galangan, Owner Surveyor, Class dan State Regulator pada kolom yang tersedia. Masing-masing kolom diisikan simbol O, R atau (-). Simbol O berarti item diperiksa oleh pihak bersangkutan, Simbol R berarti item diperiksa secara acak oleh pihak bersangkutan, Simbol (-) berarti item tidak diperiksa oleh pihak bersangkutan. Serta diisikan pula standar permiksaan yang digunakan dalam pemeriksaan.

Pihak Admin dapat memasukkan data hasil pemeriksaan yang sudah dilakukan, pada form pemeriksaan yang tersedia di dalam aplikasi yang menampilkan item-item pemeriksaan sperti pada Gambar 6. Aplikasi menyediakan item-item pemeriksaan yang digunakan sebagai pedoman pemeriksaan di lapangan.

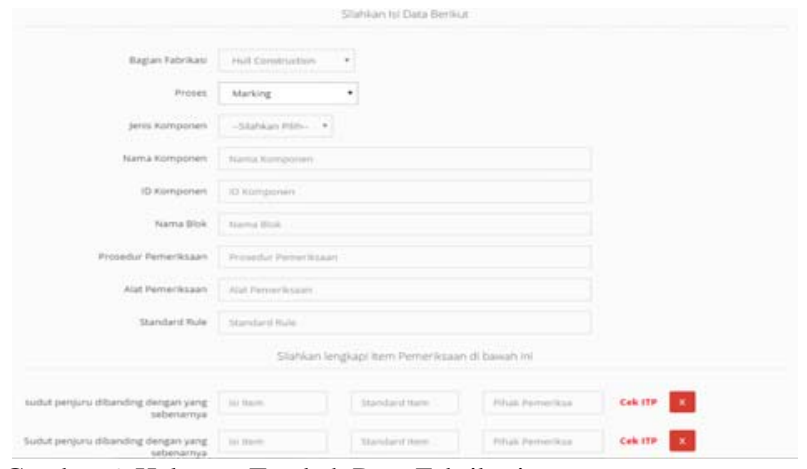

Gambar 6. Halaman Tambah Data Fabrikasi

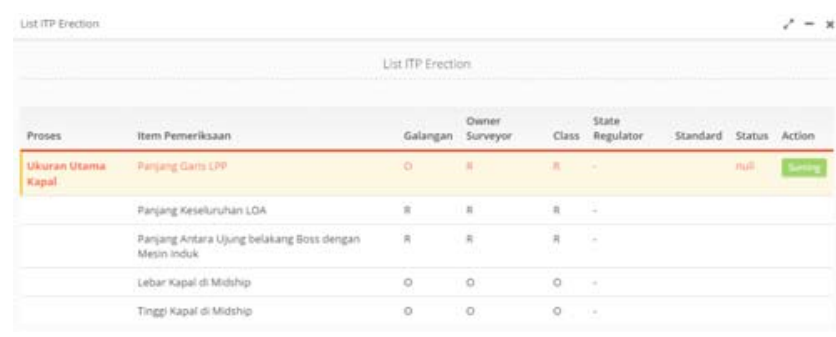

Gambar 7. Halaman Lihat ITP

Pada Gambar 7, Pihak Admin dapat melihat hasil input ITP pada sub menu lihat ITP yang tersedia, pihak Admin dapat melihat pihak-pihak mana saja yang terlibat dalam sebuah pemeriksaan. Data ITP dapat dilakukan perubahan dengan mengklik action sunting yang tersedia.

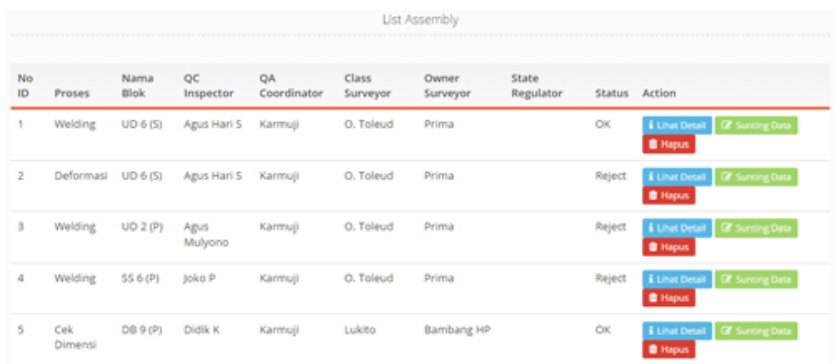

Gambar 8. Halaman Lihat List Data Assembly

Seperti pada Gambar 8., terlihat data hasil pemeriksaan dari tahapan assembly. Pihak Admin dapat melihat detail data, menyunting data dan menghapus data melalui kolom action yang tersedia.

Di dalam menu tambahan, setiap menu memiliki fungsi masing - masing. Menu Search digunakan untuk melihat data hasil pemeriksaan secara langsung dengan mengetik nama komponen, outfitting, pengujian, dokumen ataupun range tanggal pemeriksaan didalam kolom. Menu Reject digunakan untuk memudahkan semua pihak terkait, dalam melihat hasil pemeriksaan dengan status Reject di setiap tahapan. Menu Report, digunakan untuk memudahkan semua pihak terkait dalam melihat apa saja item yang sudah diperiksa oleh pihak Owner Surveyor, Class, dan State Regulator. Menu Evaluasi digunakan untuk memudahkan semua pihak terkait, dalam melihat pemeriksaan apa saja yang sudah diterima dan ditolak oleh pihak Galangan, Owner Surveyor, Class, dan State Regulator di setiap tahapan. Menu Rekomendasi digunakan untuk memudahkan semua pihak terkait dalam memberikan kritik dan saran terhadap proses pembangunan kapal.

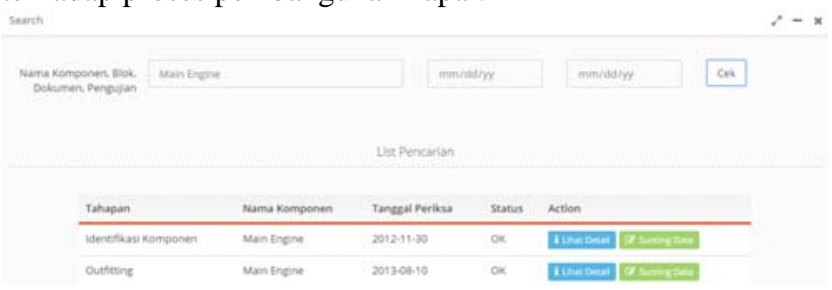

Gambar 9. Halaman Search Data

Pada Gambar 9, pihak Admin melakukan pencarian data Main Engine pada menu search, maka muncul hasil * pemeriksaan Main Engine di semua tahapan.

2. User

Simulasi aplikasi manajemen mutu untuk User adalah sebagai berikut,

a. Login

Pada halaman login, User (QA, QC, Desain, Pengadaan, Produksi, Owner Surveyor, State Regulator dan Class) memasukkan Username dan password untuk bisa mengakses menu didalam aplikasi. Dengan mengklik tombol log in maka bisa masuk ke dalam aplikasi. Pihak User yang belum terdaftar di dalam aplikasi, harus melakukan regristasi terlebih dahulu pada menu registrasi yang terdapat pada halaman login. Terdapat dua pilihan User yaitu Internal Galangan (QA, QC, Produksi, Desain dan Pengadaan) dan Eksternal Galangan (Owner Surveyor, Class dan State Regulator) seperti Gambar 10. 


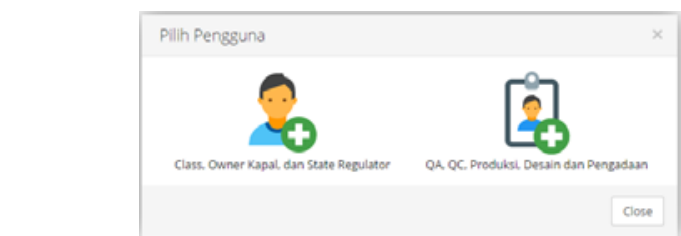

Gambar 10. Registrasi User

\section{b. Menu}

Menu aplikasi dari pihak User sama seperti menu dari pihak Admin yang membedakan hanyalah hak akses dari User hanya bisa melihat data, mencetak data dan mengunduh data. Sub menu yang tersedia pada User yaitu lihat ITP dan lihat Data.

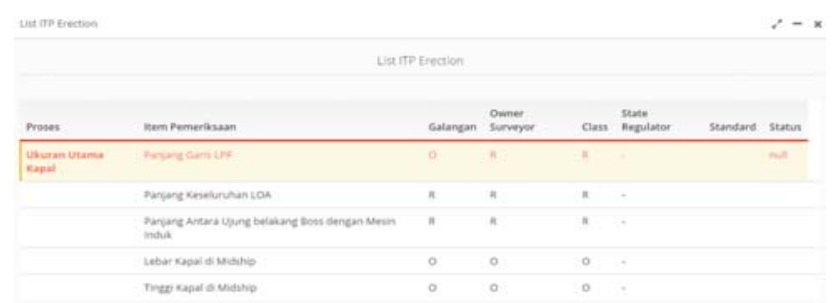

Gambar 11. Halaman Lihat ITP

Seperti pada Gambar 11, tampilan sub menu lihat ITP pihak User. Pada gambar terlihat User melihat ITP untuk tahapan Erection.

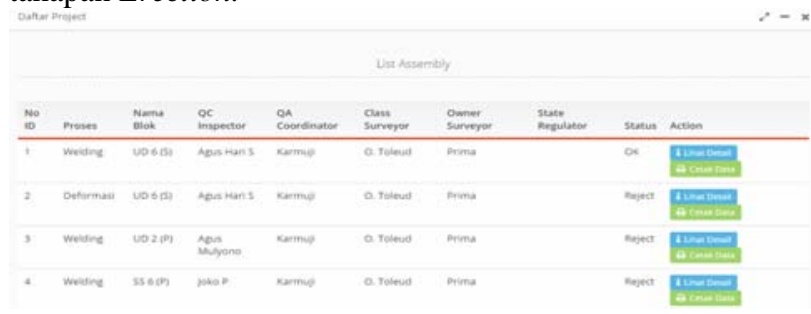

Gambar 12. Halaman Lihat Data Assembly

Seperti pada Gambar 12, tampilan sub menu lihat Data Assembly pihak User. User hanya bisa melihat detail dan cetak data. Jika meng-klik lihat detail muncul tampilan seperti Gambar 13 dan dengan meng-klik cetak data muncul tampilan seperti Gambar 14.

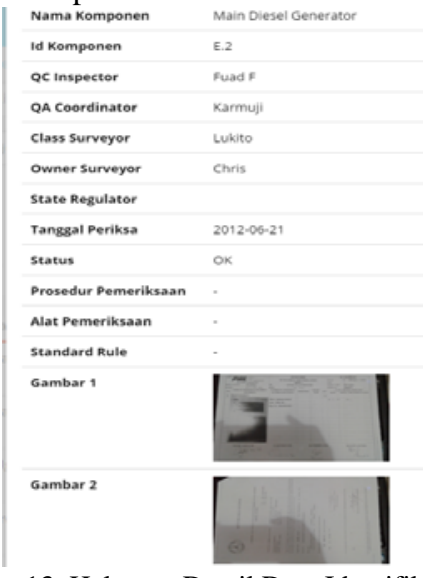

Gambar 13. Halaman Detail Data Identifikasi Komponen

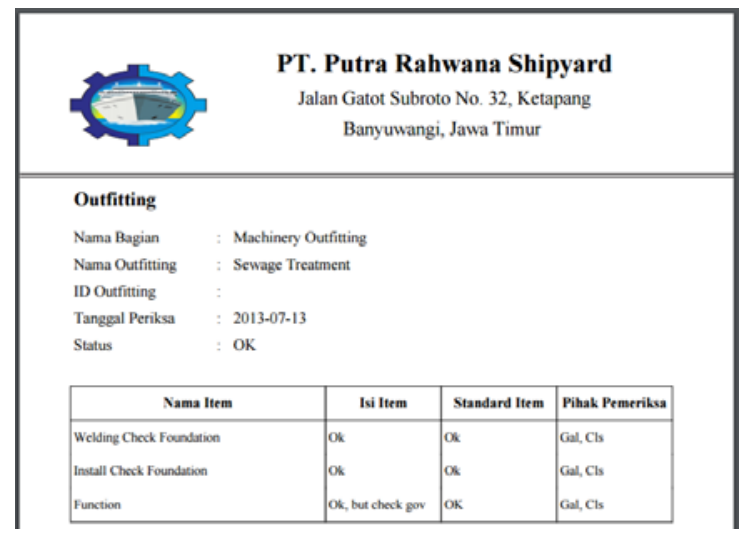

Gambar 14. Halaman Cetak dan Unduh Data Outfitting

Di dalam menu search, reject, report, evaluasi dan rekomendasi, pihak User hanya bisa melakukan lihat data dan cetak data. Fungsi dari menu-menu tersebut pada pihak User sama seperti pada pihak Admin.

\section{ANALISIS APLIKASI}

Aplikasi manajemen mutu dapat membantu dalam pelaksanaan manajemen pemeriksaan di Galangan Kapal dalam mengawasi, mencari, menampilkan, mengevaluasi dan melaksanakan pemeriksaan. Dalam melakukan review pemeriksaan, sistem aplikasi hanya memerlukan waktu 10 menit, sedangkan sistem eksisting jarang sekali bahkan tidak pernah dilakukan review pemeriksaan. Dalam penyaluran hasil pemeriksaan, sistem aplikasi hanya memerlukan waktu 7 menit dibandingkan dengan sistem eksiting yang butuh 1 hari. Sedangkan dalam pencarian pemeriksaan, sistem aplikasi hanya memerlukan waktu 8 menit dan sistem eksisting yang butuh 3 jam. Sistem eksisting tidak dapat melakukan kontrol dan evaluasi secara langsung terhadap pemeriksaan, untuk proses evaluasi saat ini dilakukan hanya tiap 3 bulan. Sistem aplikasi yang dirancang memiliki sistem kontrol dan evaluasi secara langsung terhadap pemeriksaan, sehingga proses kontrol dan evaluasi dapat dijalankan sewaktu - waktu.

Tabel 1. Hasil Uji Verifikasi Aplikasi

\begin{tabular}{|c|c|c|c|c|c|c|c|c|}
\hline No & Pertanyaan & $\mathbf{K}$ & C & B & SB & $\begin{array}{c}\text { Tota } \\
\text { I }\end{array}$ & Mean & Ket. \\
\hline 1 & $\begin{array}{l}\text { Aplikasi } \\
\text { membantu } \\
\text { dalam } \\
\text { penyimpanan } \\
\text { hasil } \\
\text { pemeriksaan }\end{array}$ & 0 & 1 & 13 & 7 & 69 & 3.3 & SB \\
\hline 2 & $\begin{array}{l}\text { Tingkat } \\
\text { kemudahan/Use } \\
\text { r friendly } \\
\text { Aplikasi }\end{array}$ & 0 & 4 & 12 & 5 & 64 & 3.0 & B \\
\hline 3 & $\begin{array}{l}\text { Performance } \\
\text { aplikasi } \\
\text { dibandingkan } \\
\text { dengan sistem } \\
\text { yang dijalankan } \\
\text { saat ini }\end{array}$ & 0 & 1 & 13 & 7 & 69 & 3.3 & SB \\
\hline 4 & $\begin{array}{l}\text { Aplikasi } \\
\text { membantu } \\
\text { dalam review } \\
\text { pemeriksaan }\end{array}$ & 0 & 0 & 12 & 9 & 72 & 3.4 & SB \\
\hline 5 & $\begin{array}{l}\text { Aplikasi } \\
\text { membantu } \\
\text { dalam } \\
\text { pengawasan } \\
\text { pemeriksaan }\end{array}$ & 0 & 1 & 13 & 7 & 69 & 3.3 & SB \\
\hline
\end{tabular}




\begin{tabular}{lllllllll}
\hline \hline 6 & $\begin{array}{l}\text { Aplikasi } \\
\text { membantu } \\
\text { dalam evaluasi } \\
\text { pemeriksaan } \\
\text { Tingkat }\end{array}$ & 0 & 1 & 13 & 7 & 69 & 3.3 & SB \\
keamanan \\
penyimpanan \\
hasil \\
pemeriksaan \\
$\begin{array}{l}\text { Aplikasi } \\
\text { diperlukan } \\
\text { untuk } \\
\text { memperbaiki } \\
\text { sistem yang } \\
\text { dijalankan saat } \\
\text { ini }\end{array}$ & 0 & 3 & 15 & 3 & 63 & 3.0 & B \\
\hline \hline
\end{tabular}

Pada Tabel 1, dapat disimpulkan bahwa aplikasi manajemen mutu ini baik untuk diterapkan dalam pelaksanaan proses manajemen mutu pembangunan kapal baru. Pada Tabel 2, dapat dilihat hasil analisa kelemahan dan kelebihan sistem eksisting dan sistem aplikasi yang menunjukkan adanya perbedaan yang mencolok antara kedua sistem.

Tabel 2. Kelebihan dan Kelemahan Sistem Eksisting dan Sistem Aplikasi

\begin{tabular}{|c|c|c|}
\hline & Kelebihan & Kelemahan \\
\hline \multirow[t]{2}{*}{$\begin{array}{l}\text { Sistem } \\
\text { Eksis- } \\
\text { ting }\end{array}$} & $\begin{array}{l}\text { 1. Tidak tergantung } \\
\text { koneksi internet }\end{array}$ & $\begin{array}{l}\text { 1. Penyimpanan hasil pemeriksaan } \\
\text { secara terpisah - pisah } \\
\text { 2. Review pemeriksaan lebih lama } \\
\text { 3. Pelaksanaan pemeriksaan yang } \\
\text { tidak sistematis } \\
\text { 4. Tidak dapat melakukan } \\
\text { pengawasan secara bersama } \\
\text { 5. Evaluasi tidak dapat dilakukan } \\
\text { sewaktu - waktu } \\
\text { 6. Tidak dapat mengetahui kualitas } \\
\text { kapal yang dibangun } \\
\text { 7. Pencarian pemeriksaan butuh } \\
\text { waktu lama } \\
\text { 8. Bisa diserang virus }\end{array}$ \\
\hline & Kelemahan & Kelebihan \\
\hline \multirow{9}{*}{$\begin{array}{l}\text { Sistem } \\
\text { Apli- } \\
\text { kasi }\end{array}$} & \multirow{9}{*}{$\begin{array}{l}\text { 1. Kecepatan koneksi } \\
\text { tergantung jaringan } \\
\text { internet dan server. } \\
\text { 2. Bisa diserang hacker } \\
\text { dan virus. }\end{array}$} & $\begin{array}{l}\text { 1. Penyimpanan hasil pemeriksaan } \\
\text { lebih ringkas dan terpusat }\end{array}$ \\
\hline & & 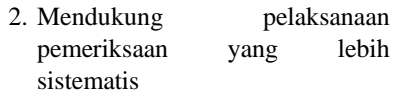 \\
\hline & & $\begin{array}{l}\text { 3. Dapat menampilkan data secara } \\
\text { mudah dan tak terbatas waktu }\end{array}$ \\
\hline & & $\begin{array}{l}\text { 4. Dapat digunakan untuk } \\
\text { pemeriksaan berbagai jenis kapal }\end{array}$ \\
\hline & & $\begin{array}{l}\text { 5. Memudahkan pengawasan } \\
\text { pemeriksaan secara bersama }\end{array}$ \\
\hline & & $\begin{array}{l}\text { 6. Mengevaluasi pemeriksaan } \\
\text { dengan cepat }\end{array}$ \\
\hline & & $\begin{array}{l}\text { 7. Mengetahui tingkat kualitas } \\
\text { kapal yang dibangun }\end{array}$ \\
\hline & & $\begin{array}{l}\text { 8. Memudahkan dalam pencarian } \\
\text { pemeriksaan }\end{array}$ \\
\hline & & $\begin{array}{l}\text { 9. Memudahkan semua pihak terkait } \\
\text { untuk mencetak dan menyimpan } \\
\text { hasil pemeriksaan. }\end{array}$ \\
\hline
\end{tabular}

\section{KESIMPULAN}

Kesimpulan yang dapat diambil dari penelitian ini adalah sebagai berikut:

1. Proses manajemen mutu di galangan kapal saat ini belum terlaksana secara sistematis. Manajemen pemeriksaan belum didukung dengan sistem yang mempermudah pihak Galangan, Owner Surveyor, Class dan State Regulator dalam pengawasan, pencarian, review, evaluasi dan pelaksanaan pemeriksaan.
2. Parameter yang terdapat dalam aplikasi diidentifikasi selama tahapan pembangunan kapal, proses, komponen kapal dan dokumen kapal, serta item pemeriksaan dan standar pemeriksaan yang bersumber pada ITP (Inspection Test Plan), standar galangan, IACS Shipbuilding Standard dan rule Class.

3. Perancangan aplikasi dilakukan melalui beberapa tahapan yaitu pemodelan aplikasi, perancangan interface, perancangan database dan pengkodingan aplikasi. Software yang digunakan merupakan kombinasi database MySQL, bahasa pemograman PHP dan Text Editor Sublime Text 2. Berdasarkan hasil uji verifikasi dan perbandingan sistem, Aplikasi manajemen mutu yang dirancang dapat melakukan pengawasan, pencarian, review, evaluasi, dan pelaksanaan pemeriksaan. Responden (Pengguna aplikasi) menilai aplikasi cukup baik untuk digunakan dalam membantu proses manajemen mutu pada pembangunan kapal baru.

\section{UCAPAN TERIMA KASIH}

Penulis mengucapkan terima kasih kepada pihak yang membantu penyelesaian Tugas Akhir ini, yaitu: Bapak Ir. Triwilaswandio Wuruk Pribadi, M.Sc. selaku Dosen Pembimbing, Bapak Dr. Ir. I Ketut Suastika selaku Dosen Wali, Ibu Sri Rejeki Wahyu Pribadi, Bapak Sufian, Kedua Orang Tua, dan Keluarga yang selalu memberikan semangat kepada penulis.

\section{DAFTAR PUSTAKA}

[1] PT. PAL Indonesia. (2015). “Proses Bisnis Divisi Jaminan Kualitas dan Standarisasi”. Surabaya : PT. PAL Indonesia.

[2] Prihantoro, C. Rudy. (2012). “Konsep Pengendalian Mutu”. Bandung : PT. Remaja Rosdakarya.

[3] Wahyuddin. (2011). “Teknik Produksi Kapal”. Makassar : Jurusan Teknik Perkapalan, Universitas Hasanudin.

[4] Yakub. (2012). "Pengantar Sistem Informasi”. Yogyakarta : Graha Ilmu.

[5] Kusuma, YM Ardhana. (2014). "Project PHP \& MySQL : Membuat Website Buku Digital”. Jasakom.

[6] Al Fatta, Hanif. (2007). “Analisis dan Perancangan Sistem Informasi untuk Keunggulan Bersaing Perusahaan dan Organisasi Modern”. Yogyakarta : Andi. 